\title{
PENGATURAN TINDAK PIDANA KORUPSI (SUAP) MENURUT HUKUM PIDANA INDONESIA DAN HUKUM PIDANA MALAYSIA
}

\author{
Adinda Febriana ${ }^{1)}$, Viona Salsabila ${ }^{2)}$ \\ 1)Mahasiswa Fakultas Hukum Universitas Jambi \\ 2)Mahasiswa Fakultas Hukum Universitas Muara Bungo \\ vionasalsabila53@gmail.com, adindafebriana14@yahoo.co.id
}

\section{RINGKASAN}

Artikel ini bertujuan untuk melihat perbandingan antara dua hukum di dua negara yaitu Indonesia yang menggunakan Undang-Undang Nomor 31 Tahun 1999 jo Undang-Undang Nomor 20 Tahun 2001 dan Malaysia yang menggunakan Akta Suruhanjaya Pencegahan Rasuah Malaysia 2009 (Akta SPRM 2009) atau Akta 694. Pengaturan bentuk tindak pidana korupsi (suap) dalam hukum pidana Indonesia dan hukum pidana Malaysia yang memiliki beberapa persamaan baik dalam pengaturan rumusan tindak pidana nya maupun dalam pengaturan sanksi pidana. Baik Indonesia maupun Malaysia memiliki keunggulan dan kelemahan dalam pengaturan tindak pidana suap. Kesimpulan: Dalam Undang Undang Pemberantasan Tindak Pidana Korupsi dan Akta Surahanjaya Pencegah Rasuah Malaysia 2009 memiliki persamaan dan perbedaan tindak pidana korupsi (suap) yang meliputi subjek hukum, unsur-unsur pada pasal, bentuk suapan, rumusan sanksi yang digunakan, pola perumusan pidana, pola ancaman pidana, dan besaran ancaman pidana.

\section{Kata kunci :Perbandingan, Tindak Pidana Suap, Indonesia, Malaysi}

\section{PENDAHULUAN}

Indonesia merupakan negara hukum, hal ini termuat dalam Pasal 1 ayat (3) Undang-Undang Dasar Negara Republik Indonesia Tahun 1945. Negara hukum yang dimaksud adalah setiap langkah pergaulan hidup manusia dalam kehidupan bermasyarakat, berbangsa dan bernegara tidak lepas dari norma hukum yang merupakan tata aturan yang dapat dijadikan pedoman atau pegangan dalam usaha mewujudkan ketentraman dan kedamaian dalam bermasyarakat. Indonesia terdapat hukum publik, hukum privat, hukum adat dan sebagian hukum islam yang mana hukum-hukum tersebut mengacu pada tujuan pembangunan nasional.

Pembangunan nasional bertujuan mewujudkan keadaan manusia yang adil, makmur dan sejahtera berdasarkan Pancasila dan Undang-Undang Dasar 1945. Untuk mewujudkan masyarakat Indonesia yang adil, makmur, dan sejahtera perlu secara terus menerus meningkatkan usahausaha pencegahan dan pemberantasan tindak pidana khususnya tindak pidana korupsi1.
Dalam perspektif hukum pidana Indonesia, tindak pidana korupsi tergolong sebagai kejahatan yang sangat berbahaya, kerugian keuangan negara dan perekonomian negara adalah akibat nyata yang menjadi dasar pembenaran dilakukannya kriminalisasi terhadap berbagai bentuk perilaku koruptif dalam kebijakan perundang-undangan pidana.Akan tetapi, hilangnya kepercayaan masyarakat terhadap pemerintah suatu negara justru lebih berbahaya daripada hanya sekedar kerugian dari sudut pandang keuangan dan ekonomi semata. Tindak pidana korupsi yang terjadi selama ini telah menghambat pertumbuhan dan kelangsungan pembangunan nasional yang menuntut adanya efesiensi yang tinggi. Dalam rangka mewujudkan suatu masyarakat yang adil dan makmur sebagai tujuan kebangsaaan berdasarkan pancasila dan Undang-Undang Dasar 1945, maka korupsi harus diberantas.

Tindak pidana korupsi di Indonesia sudah meluas dalam masyarakat. Perkembangannya terus meningkat dari tahun ke tahun. Meningkatnya tindak pidana korupsi yang tidak terkendali akan 
membawa bencana, tidak saja terhadap kehidupan perekonomian nasional tetapi juga pada kehidupan berbangsa dan bernegara pada umumnya. Tindak pidana korupsi merupakanpelanggaran terhadap hak sosial dan hak ekonomi masyarakat. Tindak pidana korupsi telah menjadi suatu kejahatan yang luar biasa ${ }^{2}$. Korupsi itu tidak pernah membawa akibat positif oleh sebab itu tindak pidana korupsi digolongkan ke dalam Extraordinary Crime atau kejahatan luar biasa yang telah nyata menggerogoti dan membahayakan keuangan dan perekonomian negara, sehingga diperlukan usaha yang keras.

Dalam pemberantasanya. Dalam hal memberantas korupsi bukan hanya pihak. Komisi Pemberantasan Korupsi yang harus menyelesaikannya, namun juga dibutuhkan peran serta dari masyarakat untuk membasmi kejahatan luar biasa itu. Kata korupsi berasal dari kata corrupt dan corruptus yang berarti rusak, busuk, dapat disuap dan dalam kamus bahasa indonesia korupsi berarti penggelapan uang negara, perusahaan, dan sebagaiannya untuk kepentingan pribadi dan orang lain ${ }^{3}$. Menurut Barda Nawawi Arief menyatakan bahwa tindak pidana korupsi merupakan perbuatan yang sangat tercela, terkutuk dan sangat dibenci olehmasyarakat, tidak hanya oleh masyarakat Indonesia, tetapi juga masyarakat bangsa-bangsa di dunia ${ }^{4}$

Terdapat 30 (tiga puluh) jenis tindak pidana korupsi menurut Undang- Undang Nomor 31 Tahun 1999 jo Undang-Undang Nomor 20 Tahun 2001 yang mana dikelompokan menjadi 7 (tujuh) jenis antara lain, kerugian keuangan negara, suap-menyuap, penggelapan dalam jabatan, pemerasan, perbuatan curang, benturan kepentingan dalam pengadaan, dan gratifikasi.

Banyak profesi di Indonesia yang menyalahgunakan jabatan yang di dapatkan dengan menerima suapan dari pihak lain untuk kepentingan dirinya atau kepentingan sekelompok golongan. Perbuatan suap bertentangan dengan norma kesusilaan dan norma pancasila, yang membahayakan kehidupan masyarakat dan bangsa. Kenyataan menunjukan bahwa perbuatan suap telah terjadi dalam berbagai bentukdalam masyarakat dan oleh karena itu harus segera diberantas.

Pada dasarnya suap adalah bagian dari jenis tindak pidana korupsi sehingga bilamana seseorang telah melakukan tindak pidana penyuapan maka dianggap telah melakukan tindak pidana korupsi. Menurut Poerwadminta dalam buku Dirjo Sisworo mengenai korupsi adalah perbuatan buruk yang dapat disuap 5 .

Jika dipertajam definisi suap sekedar untukmembedakan dengan korupsi adalah pemberian seseorang yang disertai dengan ajakan untuk melakukan atau tidak melakukan perbuatan yang melanggar hukum.Sedangkan pengertian korupsi dalam bahasa yang sederhana adalah menyalahgunakan jabatan untuk keuntungan pribadi maupun golongan ${ }^{6}$.

Penting untuk diperhatikan bahwa seseorang yang menerima suap berarti melakukan korupsi atau melakukan kejahatan, tetapi seseorang yang melakukan tindak pidana korupsi tidak selalu dengan cara menerima suap.

Mengingat akan hal tersebut, berbagai upaya telah dilakukan untuk mencegah dan memberantas tindak pidana korupsi. Pemerintah secara terus- menerus berusaha untuk memperbaharui peraturan dalam masalah tindak pidana korupsi menyesuaikan dengan perkembangan zaman.

${ }^{3}$ Tim Redaksi KBBI, Kamus Besar Bahasa Indonesia, Edisi ke-5, Gramedia Pustaka Utama, Jakarta, 2008, hlm. 67.

${ }^{4}$ Muladi dan Barda Nawawi Arief, Bunga Rampai Hukum Pidana, Alumni, Bandung, 1992, hlm. 133.

5Dirjo Sisworo, Korupsi dalam Pengelolaan Proyek Pembangunan, Akademia Persindo, Jakarta, 2003 , hlm. 3.

6Robert Klidgard, Penuntut Pemberantasan Korupsi dalam Pemerintahan Daerah, Yayasan Obor Indonesia dan Partnership for Govermance Reform In Indonesia, Jakarta, 2002, hlm. 3. 
Jika dilihat dari sejarah, pemberlakuan Undang-Undang tindak pidana korupsi di Indonesia dimulai dari Peraturan Penguasa Militer, No.PRT/PM/061957, Tahun 1957, Peraturan Pemberantasan Korupsi Penguasa Perang Pusat, No. PRT/Peperpu/031/1958, Undang-Undang No. 24/Prp/1960 tentang Pemberantasan Korupsi, Keppres No. 228/1967 (tanggal 2 Desember 1967), Keppres No. 12/1970 (tanggal 31 Januari 1970), Inpres No. 9/1977, Tap MPR No. XUMPR/1998 tentang pemerintahan yang bersih dan bebas KKN, Undang-undang No. 28/1999 tentang Penyelenggaraan Negara yang bersih dan bebas KKN, Undang- Undang No. 31/1999 tentang Pemberantasan Tindak Pidana Korupsi, dan yang terbaru Undang Undang No. 20 Tahun 2001 tentang perubahan atas Undang- Undang No. 31/1999 tentang Pemberantasan Tindak Pidana Korupsi .

\section{PEMBAHASAN}

Undang yang mengatur tentang tindak pidana suap yaitu Undang-Undang Nomor 31 Tahun 1999 jo UndangUndang Nomor 20 Tahun 2001. Dalam Undang-Undang tersebut terdapat 5 (lima)

jenis pasal yang terkait dengan suap menyuap antara lain:
1. Pasal 5 ayat (1) huruf a, (b) dan pasal 5 ayat (2) mengenai suap- menyuap terhadap pegawai negeri;

2. Pasal 6 ayat (1) huruf a, (b) dan pasal 6 ayat (2) mengenai suap- menyuap terhadap hakim dan advokat;

3. Pasal 11 mengenai pegawai negeri yang menerima hadiah;

4. Pasal 12 huruf a dan $b$ mengenai pegawai negeri yang menerima suap

5. Pasal 12 huruf $\mathrm{c}$ dan d mengenai hakim dan advokat yang menerima suap.

Dalam Akta Suruhan Jaya Pencegahan Rasuah Malaysia 2009 (Akta 694) terdapat 3 (tiga) jenis tindak pidana suap antara lain:

1. Seksyen 16 mengenai kesalahan menerima suapan;

2. Seksyen 17 mengenai kesalahan menerima suapan oleh ejen;

3. Seksyen 21 mengenai penyogokan pegawai awam;

4. Seksyen 22 mengenai penyogokan pegawai awam asing;

5. Seksyen 23 mengenai kesalahan menggunakan jawabatan atau kedudukan untuk suapan.

Dari kedua Pengaturan tersebut terdapat persamaan dan perbedaan terhadap rumusan Tindak Pidana Suap dalam Hukum Pidana Indonesia dan Hukum pidana Malaysia

\section{Persamaan Rumusan Tindak Pidana Suap dalam Hukum Pidana Indonesia Dan Hukum Pidana Malaysia}

Tabel 1

\begin{tabular}{|l|l|l|l|}
\hline No & Persamaan & Indonesia & Malaysia \\
\hline 1 & Subjek & $\begin{array}{l}\text { Dalam Undang-Undang } \\
\text { Penberantasan Ti ndak Pidana } \\
\text { Korupsi merumuskan bahwa } \\
\text { yang dapat dihukum adalah } \\
\text { setiap orang, penyelenggara } \\
\text { negara, dan pegawai negeri }\end{array}$ & $\begin{array}{l}\text { Dalam Akta SPRM 2009 } \\
\text { bahwa yang, merumuskan } \\
\text { adalah setiap orang, badan } \\
\text { awam, pegawai awam, } \\
\text { pegawai awam asing dan } \\
\text { ejen. }\end{array}$ \\
\hline
\end{tabular}




\begin{tabular}{|c|c|c|c|}
\hline 2 & $\begin{array}{l}\text { Unsur } \\
\text { pasal }\end{array}$ & 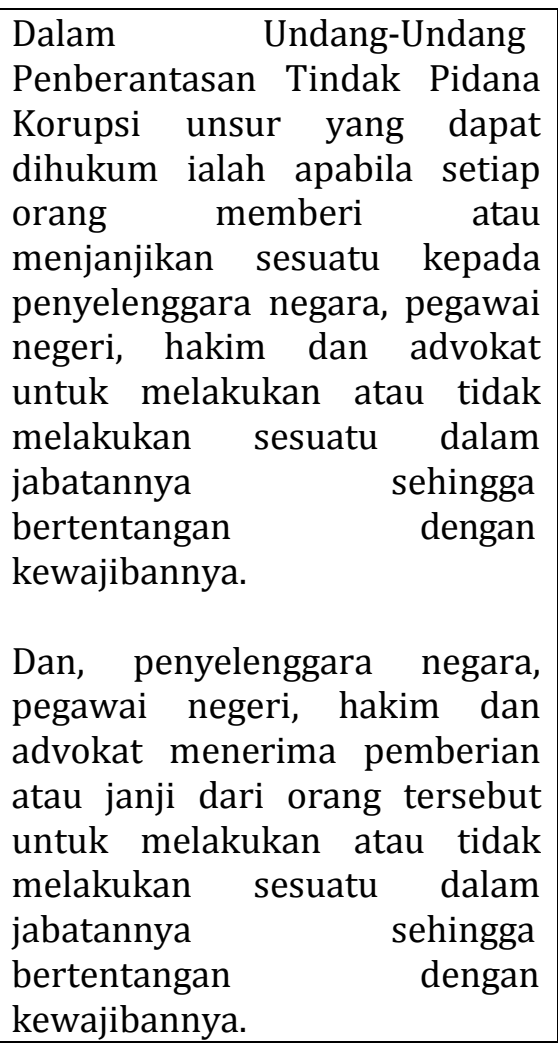 & $\begin{array}{l}\text { Dalam Akta SPRM } 2009 \\
\text { (Akta 694). Unsur yang } \\
\text { terdapat dalam tindak } \\
\text { pidana rasuah adalah mana- } \\
\text { mana orang memberikan } \\
\text { atau menjanjikan sesuatu } \\
\text { ejen atau badan awam } \\
\text { suapan sebagai dorongan } \\
\text { untuk melakukan atau tidak } \\
\text { melakukan sesuatu yang } \\
\text { berkaitan dengan } \\
\text { jabatannya. } \\
\text { Dan, badan awam atau ejen } \\
\text { yang menerima, serta } \\
\text { menyetujui suapan itu untuk } \\
\text { melakukan atau tidak } \\
\text { melakukan sesuatu yang } \\
\text { berkaitan dengan jabatan } \\
\text { serta kewenangannya. }\end{array}$ \\
\hline 3 & $\begin{array}{l}\text { Bentuk } \\
\text { Suap }\end{array}$ & $\begin{array}{l}\text { Di Indonesia, suap dapat } \\
\text { berbentuk Uang, hadiah dan } \\
\text { janji. }\end{array}$ & $\begin{array}{l}\text { Di Malaysia, suapan dapat } \\
\text { berupa } \\
\text { hadiah wang, } \\
\text { perkhitmatan, } \quad \text { jawatan, } \\
\text { pinjaman dan bonus. }\end{array}$ \\
\hline 4 & Pidana & Pidana penjara dan denda & Pidana penjara dan denda \\
\hline
\end{tabular}

Tabel 2

Perbedaan Rumusan Tindak Pidana Suap dalam Hukum Pidana Indonesia dan Hukum Malaysia

\begin{tabular}{|l|l|l|l|l|}
\hline No & Perbedaan & \multicolumn{2}{|c|}{ Indonesia } & \multicolumn{2}{|c|}{ Malaysia } \\
\hline 1. & $\begin{array}{l}\text { Banyak pasal } \\
\text { yang mengatur. }\end{array}$ & $\begin{array}{l}\text { Dalam Undang-Undang } \\
\text { Penberantasan Tindak Pidana } \\
\text { Korupsi terdapat 12 pasal } \\
\text { yang mengatur tentang tindak } \\
\text { pidana suap dari 30 Pasal. }\end{array}$ & $\begin{array}{l}\text { Dalam Akta SPRM } \\
\text { terdapat 5 seksyen } \\
\text { tentang tindak pidana } \\
\text { suap dari 16 seksyen. }\end{array}$ \\
\hline 2. & Rumusan Sanksi. & $\begin{array}{l}\text { Dalam Undang-Undang } \\
\text { Penberantasan Tindak Pidana } \\
\text { Korupsi aturan dan sanksi } \\
\text { diatur dalam pasal yang sama. }\end{array}$ & $\begin{array}{l}\text { Dalam Akta SPRM, } \\
\text { aturan dan sanksi } \\
\text { diatur dalam seksyen } \\
\text { yang berbeda. }\end{array}$ \\
\hline 3. & $\begin{array}{l}\text { Sistem } \\
\text { Perumusan }\end{array}$ & $\begin{array}{l}\text { Dalam Undang-Undang } \\
\text { Penberantasan Tindak Pidana } \\
\text { Korupsi terdapat beberapa } \\
\text { pasal yang menggunakan } \\
\text { sistem perumusan kumulatif } \\
\text { dan sistem perumusan } \\
\text { Alternatif-kumulatif }\end{array}$ & $\begin{array}{l}\text { Dalam Akta SPRM, } \\
\text { ketiga seksyen tersebut } \\
\text { menggunakansistem } \\
\text { perumusan kumulatif. }\end{array}$ \\
& & 4 & \\
\end{tabular}


Dari tabel diatas perbedaan terhadap rumusan tindak pidana suap dalam Hukum Pidana Indonesia yang menggunakan Undang-Undang Nomor 31 Tahun 1999 jo Undang-Undang Nomor 20 Tahun 2001 tentang Pemberantasan Tindak Pidana Korupsi memuat 30 (tiga puluh) jenis tindak pidana korupsi tetapi hanya 12 pasal yang mengatur tentang tindak pidana suap yaitu Pasal 5 ayat (1) huruf a, Pasal 5 ayat (1) huruf b, pasal 13, Pasal 5ayat (2), Pasal 12 huruf a, Pasal 12 huruf b, Pasal 11, Pasal 6 ayat (1) huruf a, Pasal 6 ayat (1) huruf b, Pasal 6 ayat (2), Pasal 12 huruf c, dan Pasal 12 huruf d.

Norma yang mengatur serta ancaman pidana dirumuskan dalam satu pasal, yang mana dari kedua belas jenis menggunakan kata hubung "dan/atau" seperti "pidana penjara dan/atau pidana denda.

Dalam Hukum Pidana Malaysia yang menggunakan Akta Suruhanjaya Pencegahan Rasuah Malaysia 2009 (Akta 694), terdapat 5 seksyen yang mengatur tentang tindak pidana suap yaitu seksyen 16 (a), (b), 17 (a), (b), 21,22 dan 23. Dalam pasal tersebut ada 7 (tujuh) Pasal yang menggunakan sistem perumusan kumulatif yaitu 6 ayat (1) huruf a, Pasal 6 ayat (1) huruf b, Pasal 6 ayat (2), Pasal 12 huruf a, Pasal 12 huruf b, Pasal 12 huruf c, dan Pasal 12 huruf $d$ serta 5 (lima) pasal menggunakan sistem perumusan alternatifkumulatif yaitu Pasal 5 ayat (1) huruf a, Pasal 5 ayat (1) huruf b, Pasal 5 ayat (2), Pasal 11, dam Pasal 13.

Sistem Perumusan Kumulatif yaitu sistem yang mempunyai ciri khusus yaitu adanya ancaman pidana dengan redaksional kata hubung "dan" seperti "pidana penjara dan denda", sedangkan sistem perumusan kumulatif- alternatif yaitu sistem yang ancaman pidananya diberikan dengan

Seksyen tersebut mengatur tentang perbuatan yang dilarang, dan untuk ancaman sanksi pidananya diatur dalam seksyen yang berbeda yaitu seksyen 24 . Dalam Akta SPRM 2009 (Akta 694) sistem perumusan yang digunakan untuk ancaman tindak pidana suap menggunakan sistem perumusan kumulatif yaitu menggunakan kata hubung "dan" seperti pidana penjara dan denda.

\section{A. Persamaan Dan Perbedaan Jenis Pidana Tindak Pidana Suap Menurut Hukum Pidana Indonesia Dan Hukum Pidana Malaysia.}

Tabel 3

Persamaan Jenis Pidana Tindak Pidana Suap Menurut Hukum Pidana Indonesia dan Hukum Pidana Malaysia

\begin{tabular}{|c|c|c|c|}
\hline No & Persamaan & UU PTPK & Akta SPRM 2009 \\
\hline 1. & $\begin{array}{l}\text { Bentuk Tindak } \\
\text { Pidana }\end{array}$ & $\begin{array}{l}\text { Tindak Pidana Korupsi } \\
\text { dalam kategori Suap }\end{array}$ & Tindak Pidana Rasuah. \\
\hline 2. & Jenis Pidana & $\begin{array}{l}\text { Menggunakan Pidana } \\
\text { Penjara dan juga } \\
\text { menggunakan Pidana } \\
\text { Denda }\end{array}$ & $\begin{array}{l}\text { Menggunakan Pidana } \\
\text { Penjara dan juga } \\
\text { menggunakan Pidana } \\
\text { Denda }\end{array}$ \\
\hline 3 & Ancaman Pidana & $\begin{array}{l}\text { Penjara tidak lebih dari } 20 \\
\text { tahun }\end{array}$ & $\begin{array}{l}\text { Penjara tidak lebih } 20 \\
\text { Tahun }\end{array}$ \\
\hline 3 & $\begin{array}{l}\text { Alternatif Untuk } \\
\text { Denda }\end{array}$ & $\begin{array}{l}\text { Denda bisa di ganti } \\
\text { menjadi penjara. }\end{array}$ & $\begin{array}{l}\text { Denda bisa di ganti } \\
\text { menjadi penjara. }\end{array}$ \\
\hline
\end{tabular}

Dari Tabel diatas terlihat persamaan jenis pidana tindak pidana suap malaysia yaitu Akta SPRM 2009 (Akta 694) bahwa tindak pidana yang dilakukan sama yairu tindak pidana Suap. Kedua aturan ini menurut hukum pidana indonesia yaitu UU PTPK dan hukum pidana menggunakan pidana penjara dengan ketentuan yakni sama-sama menentukan batas maksimal pidana penjara adalah 20 (dua puluh) tahun dan pidana denda 
sebagai pidana pokok dan jika tidak bisa membayar denda maka ancaman pidana denda di kumulatifkan menjadi pidana penja

ra.

Tabel 4

\section{Perbedaan Jenis Pidana Tindak Pidana Suap Menurut Hukum Pidana Indonesia dan Hukum Pidana Malaysia}

\begin{tabular}{|l|l|l|l|}
\hline No & \multicolumn{1}{|c|}{ Perbedaan } & \multicolumn{1}{|c|}{ Indonesia } & \multicolumn{1}{|c|}{ Malaysia } \\
\hline 1. & $\begin{array}{l}\text { Pola Perumusan } \\
\text { Pidana }\end{array}$ & $\begin{array}{l}\text { Pidana Kumulatif dan Pidana } \\
\text { Kumulatif-Alternatif }\end{array}$ & Pidana Kumulatif \\
\hline 2. & $\begin{array}{l}\text { Pola ancaman } \\
\text { pidana }\end{array}$ & $\begin{array}{l}\text { Menggunakan pola maksimum } \\
\text { khusus dan minimum khusus }\end{array}$ & $\begin{array}{l}\text { Menggunakan pola } \\
\text { minimum umum. }\end{array}$ \\
\hline 3 & $\begin{array}{l}\text { Besaran Ancaman } \\
\text { Pidana }\end{array}$ & $\begin{array}{l}\text { Dalam Undang-Undang } \\
\text { Penberantasan Tindak Pidana } \\
\text { Korupsi Ancaman pidana penjara } \\
\text { berkisar antara 1 tahun sampai } \\
\text { dengan 20 tahun atau seumur hidup } \\
\text { dan pidana denda nya berkisar } \\
\text { antara 50 } \\
\text { juta rupiah sampai dengan 1 milyar } \\
\text { rupiah. }\end{array}$ & $\begin{array}{l}\text { Dalam Akta SPaman } \\
\text { Ancaman } \\
\text { penjaranya dari 1 han } \\
\text { sampai dengan } \\
\text { 20 tahun dan dendanya } \\
\text { dikali 5 kali suapan. }\end{array}$ \\
\hline
\end{tabular}

Dari Tabel diatas terdapat beberapa perbedaan yaitu pola perumusan pidananya di Undang-Undang Penberantasan Tindak Pidana Korupsi pola perumusannya Kumulatif dan Kumulatif Alternatif. Pasal yang menggunakan pola perumusan Kumulatif yaitu:

1. Pasal 6 ayat (1) huruf a dan huruf b.

Ancaman pidana penjara minimum 3 (tiga) tahun dan maksimum 15 (lima belas) tahun dan pidana denda minimum Rp 150.000.000,00 (seratus lima puluh juta rupiah) dan maksimum Rp 750.000.000,00 (tujuh ratus lima puluh juta rupiah.

2. Pasal 6 ayat (2)

Ancaman pidana penjara minimum 3 (tiga) tahun 3 (tiga) tahun dan maksimum 15 (lima belas) tahun dan pidana denda minimum Rp. 150.000.000,00 (seratus lima puluh juta rupiah) dan maksimum Rp. $750.000 .000,00$ (tujuh ratus lima puluh juta rupiah).

3. Pasal 12 huruf a, b, c, dan d.

rupiah) dan maksimum Rp.

$250.000 .000,00$ (dua ratus lima puluh juta rupiah).

3. Pasal 11
Ancaman pidana penjara seumur hidup atau pidana penjara minimum 4 (empat) tahun dan maksmimum 20 (dua puluh) tahun dan pidana denda minimum Rp 200.000.000,00 (dua ratus juta rupiah) dan maksimum Rp 1.000.000.000,00 (satu miliar rupiah).

Pasal yang menggunakan Pola perumusan Kumulatif-Alternatif, yaitu:

1. Pasal 5 ayat (1) huruf a dan b.

Ancaman pidana penjara minimum 1 (satu) tahun dan maksimum 5 (lima tahun) dan/atau denda minimum $50.000 .000,00$ (lima puluh juta rupiah) dan maksimum Rp. 250.000.000,00 (dua ratus lima puluh juta rupiah).

2. Pasal 5 ayat (2)

Ancaman pidana penjara minimum 1 (satu) tahun dan maksimum 5 (lima tahun) dan/atau denda minimum 50.000.000,00 (lima puluh juta

Ancaman pidana penjara minimum 1 (satu) tahun dan maksimum 5 (lima tahun) dan/atau denda minimum 50.000.000,00 (lima puluh juta rupiah) dan 
maksimum Rp. 250.000.000,00 (dua ratus lima puluh juta rupiah).

\section{Pasal 13}

Ancaman pidana maksimum 3 (tiga tahun) dan/atau denda paling banyak Rp. 150.000.000,00 (seratus lima puluh juta rupiah). Dalam pasal ini pola perumusan yang dipakai minimum umum, yaitu ancaman pidana minimum 1 (satu) hari. Dalam Akta SPRM 2009 (Akta 694), Ancaman pidana diatur dalam seksyen 24, yaitu (1) Mana-mana orang yang melakukan kesalahan di bawah seksyen 16, 17, 20, 21, 22 dan 23 apabila disabitkan boleh:

(a) dipenjarakan selama tempoh tidak melebihi dua puluh tahun dan;

(b) didenda tidak kurang daripada lima kali ganda jumlah atau nilai suapan yang menjadi hal perkara kesalahan Suruhanjaya Pencegahan Rasuah Malaysia 29 itu jika suapan itu dapat dinilai atau berbentuk wang, atau sepuluh ribu ringgit, mengikut manamana yang lebih tinggi.

Akta SPRM 2009 (Akta 694) menggunakan pola perumusan kumulatif dengan menggunakan kata hubung "dan" untuk pidana penjara dan denda

yang artinya bahwa kedua-dua jenis pidana itu haruslah dilakukan oleh si terdakwa apabila telah diputuskan oleh hakim untuk penjatuhan pidana. Dalam Akta SPRM 2009 (Akta 694) terlihat bahwa aturan ini menggunakan pola minimum umum pidana penjara yaitu 1 (satu) hari sampai dengan 20 (dua) puluh tahun dan dengan denda 5 (lima) kali suapan. Jika seseorang menerima/memberi suapan sebesar Rp.2.000.000,00 (Dua juta rupiah) maka ia harus membayar denda sebesar Rp. 10.000.000,- (Sepuluh juta rupiah).

Dari uraian di atas terlihat perbedaan antara hukum pidana Indonesia dan hukum pidana Malaysia dalam hal tindak pidana suap khususnya dalam penjatuhan denda bagi pelaku tindak pidana suap. Namun, Indonesia dan
Malaysia memiliki caranya sendiri untuk menangani masalah tindak pidana suap yang memiliki tujuan yang sama yaitu untuk memberantas tindak pidana suap agar tercapainya negara bersih tanpa korupsi.

1. Dalam rumusan tindak pidana korupsi (suap) menurut Hukum Pidana Indonesia yaitu Undang-Undang Nomor 31 Tahun 1999 Jo Undang- Undang Nomor 20 Tahun 2001 Tentang Pemberantasan Tindak Pidana Korupsi dan Hukum Pidana Malaysia yaitu Akta Suruhanjaya Pencegahan Rasuah Malaysia 2009 (Akta 694) memiliki persamaan yang meliputi subjek hukum pelaku tindak pidana suap, unsur pada pasal, bentuk suapan, dan pidana yang diancamkan. Sedangkan perbedaanya meliputi jumlah pasal yang mengatur tindak pidana suap, rumusan ancaman pidana yang digunakan, dan sistem perumusan ancaman pidana.

Jenis pidana dalam tindak pidana korupsi (suap) menurut Hukum Pidana Indonesia yaitu Undang-Undang Nomor 31 Tahun 1999 Jo Undang- Undang Nomor 20 Tahun 2001 Tentang Pemberantasan Tindak Pidana Korupsi dan Hukum Pidana Malaysia yaitu Akta Suruhanjaya Pencegahan Rasuah Malaysia 2009 (Akta 694) memiliki persamaan yang meliputi Bentuk tindak pidana dan jenis pidana. Sedangkan perbedaanya meliputi pola perumusan pidana, pola ancaman pidana, dan besaran ancaman pidana dan serta Indonesia dan Malaysia memiliki keunggulan serta kelemahan masingmasing dalam memberantas tindak pidana suap

\section{KESIMPULAN}

Indonesia memiliki pengaturan tentang Pemberantasan Tindak Pidana Korupsi ini sejak tahun 2002 namun sampai saat ini tindak pidana korupsi khususnya masalah suap makin merajalela. Para terdakwa kasus tindak pidana korupsi ini belum merasa jera atas hukuman yang telah diberikan kepadanya dan kerugian negara 
juga tidak sepenuhnya kembali. Oleh karena itu, dengan mengikuti ancaman denda di negara Malaysia seperti membayar denda dengan 5 kali lipat dari apa yang ia terima atau yang ia berikan dapat memberikan efek jera bagi pelaku dan membuat rasa takut bagi pejabat negara lainnya dan secara otomatis dapat mengembalikan kerugian negara sekaligus menambah pemasukan negara.

Artikel ini mengharapkan adanya perbaikan atau penambahan aturan dari Undang-Undang Tindak Pidana Pemberantasan Korupsi terkait ancaman pidana tindak pidana korupsi khususnya dalam penjatuhan ancapaman pidana masalah suap agar memberikan efek jera bagi para pelaku dan memberikan rasa takut bagi yang lain untuk melakukan transaksi suap-menyuap.

\section{DAFTAR PUSTAKA}

\section{A. Buku-Buku}

Arief, Barda Nawawi. Perbandingan Hukum Pidana. Edisi Revisi Cetakan 11. Rajawali Pers, Jakarta, 2014.

Atmasasmita, Romly. Perbandingan Hukum Dalam Sistem Peradilan Pidana, Gramedia, Bandung, 2000.

Perbandingan Hukum Pidana, Mandar Maju, Bandung, 1996.

Sekitar Masalah Korupsi Aspek Nasional dan Aspek Internasional, Mandar Maju, Bandung, 2004.

Beni Ahmad Saebani, Syahrul Anwar, dan Ai Wati, Perbandingan Sistem Hukum Pidna, Pustaka Setia, Bandung, 2016.

Chazawim, Adami. Stelsel Pidana Tindak Pidana TeoriTeori Pemidanaan dan batas berlakunya hukum pidana Pelajaran Hukum Pidana I, Rajawali Pers, Jakarta, 2011.
Djaja, Ermansjah. Meredesain Pengadilan Tindak Pidana Korupsi Implikasi Putusan Mahkamah Konstitusi Nomor 012-016-019/PPU-IV/2006.

SinarGrafika, Jakarta, 2010.

Memberantas Korupsi Bersama KPK Kajian Yuridis Normatif UU Nomor 31 Tahun 1999 juncto UU Nomor 20 Tahun 20011 Versi UU Nomor 30 Tahun 2002, Edisi Pertama, Cetakan Kedua, Sinar Grafika, Jakarta, 2009.

Hamzah, Andi. Pemberantasan Korupsi Melalui Hukum Pidana Nasional dan Internasional, Raja Grafindo, Jakarta, 2006.

Hartanti, Evi. Tindak Pidana Korupsi, Edisi Kedua, Sinar Grafika, Jakarta, 2012. Kanter E.Y dan S.R. Sianturi, Asas-Asas Hukum Pidana di Indonesia dan

Penerapannya, Cet.3, Storia Grafika, Jakarta, 2012.

Klidgard, Robert. Penuntut Pemberantasan Korupsi dalam Pemerintahan Daerah. Yayasan Obor Indonesia dan Partnership for Govermance Reform In Indonesia, Jakarta, 2002.

Kristian dan Yopi Gunawan, Tindak PIdana Korupsi Kajian Terhadap Harmonisasi antara Hukum Nasional dan The United National Convention Against Corruption (UNCAC), Refika Aditama, Bandung, 2015.

Maheka, Arya, Mengenali dan Memberantas Korupsi, Komisi Pemberantasan Korupsi. Jakarta, 2007.

Marzuki, Peter Mahmud. Penelitian Hukum, Kencana, Jakarta. 2006. 
Moeljatno. Asas-Asas Hukum Pidana. Bina Aksara, Jakarta, 2009.

Muladi dan Barda Nawawi, Teori-Teori Dan Kebijakan Pidana, Cetakan Keempat .PT Alumni, Bandung, 2010.

Peter de Cruz, Perbandingan Sistem Hukumcivil Law, Common Law, Socialist Law, Nusa Media, Jakarta, 2014.

Projodikoro, Wirjono. Asas-Asas Hukum Pidana di Indonesia, Edisi Kedua, Cetakan Keempat, Eresco, Bandung, 1986.

Poernomo, Bambang. AsasAsas Hukum Pidana. Ghalia Indonesia, Jakarta, 1994. Qamar, Nurul, Perbandingan Sistem Hukum Dan Peradilan Civil Law System

Dan Common Law System, Pustaka Refleksi, 2010.

Sisworo, Dirjo. Korupsi dalam Pengelolaan Proyek Pembangunan, Akademia Persindo. Jakarta, 2002.

Suherman, Ade maman, Pengantar Perbandingan Sistem Hukum, PT raja grafindo persada, 2006.

Syamsudin, Aziz. Tindak Pidana Khusus, Cetakan Ket3, Sinar Grafika, Jakarta, 2013.

Wiyanto, Romi. Asas-Asas Hukum Pidana Indonesia. MandarMaju, Bandung, 2012.

Zulkarnain Abdul Rahman, dkk, Sejarah perjuangan SPRM Satu Perjalanan, Penerbit Universiti Malaya, Malaysia, 2017.

B. Jurnal
Adly, Pidana Denda dan Uang

Pengganti Terhadap

Terpidana dalam Tindak

Pidana Korupsi (Studi

Komperatif hukum Indonesia

dan Malaysia), Universitas

Jambi, 2017.

Astim Riyanto, Sistem Hukum Negara-Negara Asia Tenggara, Jurnal Hukum dan Pembangunan Tahun Ke-37 No.2 April-Juni 2007, Bandung, 2007.

Hendra Yospin. Studi Komperatif Terhadap strategi pencegahan dan pemberantasan tindak pidana korupsi di Indonesia dan Malaysia, Disertasi, Universitas Jambi, 201 
